\title{
Medication adherence and glycemic control among diabetes patients in developing countries
}

\author{
Saurav Basu(0)
}

\begin{abstract}
The potential interconnectedness of medication adherence, glycemic control, and clinical inertia in resourceconstrained settings of the developing world needs further evaluation.
\end{abstract}

Keywords: Diabetes, Adherence, Glycemic control, Developing countries

\section{Dear Editor,}

Low- and middle-income countries account for $80 \%$ of the global diabetes burden [1]. Moreover, it is well established that suboptimal medication adherence in diabetes patients due to lack of timely refill replenishment arising from health system and socioeconomic factors is a major public health challenge in developing countries [2].

The study by Rathish et al. from a rural province in Sri Lanka makes an important contribution to the sparse literature on the subject in the country and establishes the benefits of government-funded universal free-health services in enhancing medication coverage and adherence in low-income diabetes patients [3]. However, there are certain concerns regarding the study methodology and interpretation that are discussed below.

The researchers applied the Morisky-Green-Levine scale to assess medication adherence in diabetes patients. The scale has low sensitivity and doubtful validity in this patient population that is further lowered by the application of a cutoff score of 2 that indicates moderate adherence only which might be inadequate in the attainment of good glycemic control. The direct comparison of the rates of adherence of this study with other studies that applied a different medication adherence scale and/ or a different adherence definition is inappropriate as more sensitive scales and a more stringent definition of non-adherence could yield different adherence rates.

Correspondence: saurav.basu1983@gmail.com

Department of Community Medicine, Maulana Azad Medical College,

Bahadur Shah Zafar Marg, New Delhi 110002, India
A major limitation of the present study is also the lack of reporting of glycemic control status in the patients. This is particularly important for the identification of the phenomenon of clinical or therapeutic inertia indicating the failure to adequately intensify the treatment in patients showing poor glycemic control that increases the risk of incident diabetes-related complications. Previous studies from government tertiary care hospitals in India that provide free medication coverage have observed a high prevalence of poor glycemic control despite good anti-diabetes medication adherence rates in the patients $[4,5]$. This has been attributed to clinical inertia from limited availability of anti-diabetic drug armamentarium and failure of a timely switch to insulin therapy [6, 7]. A study in Brazil also observed a high-rate of clinical inertia during diabetes care [8]. The Rathish et al. [3] study had reported the lack of availability of some anti-diabetes agents like DPP-4 inhibitors in the free service compared to the paid service which could have significant implications on patient glycemic status. Future studies from the region should therefore evaluate the potential interconnectedness of adherence, glycemic control, and clinical inertia in their settings.

\section{Acknowledgements}

None

\section{Authors' contributions}

SB contributed to the manuscript preparation, literature search, and intellectual content. The author read and approved the final manuscript.

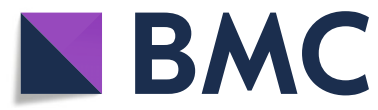

(C) The Author(s). 2019 Open Access This article is distributed under the terms of the Creative Commons Attribution 4.0 International License (http://creativecommons.org/licenses/by/4.0/), which permits unrestricted use, distribution, and reproduction in any medium, provided you give appropriate credit to the original author(s) and the source, provide a link to the Creative Commons license, and indicate if changes were made. The Creative Commons Public Domain Dedication waiver (http://creativecommons.org/publicdomain/zero/1.0/) applies to the data made available in this article, unless otherwise stated. 
Availability of data and materials

Not applicable

Ethics approval and consent to participate

Not applicable

\section{Consent for publication}

Not applicable

\section{Competing interests}

The author declares that he/she has no competing interests.

Received: 26 February 2019 Accepted: 28 October 2019

Published online: 12 November 2019

\section{References}

1. International Diabetes Federation. IDF diabetes atlas. Brussels: International Diabetes Federation; 2017.

2. World Health Organization. Global Report on Diabetes. Geneva: World Health Organization; 2016.

3. Rathish D, Hemachandra R, Premadasa T, Ramanayake S, Rasangika C, Roshiban $\mathrm{R}$, et al. Comparison of medication adherence between type 2 diabetes mellitus patients who pay for their medications and those who receive it free: a rural Asian experience. J Health Popul Nutr. 2019:38(1):4.

4. Basu S, Khobragade M, Kumar A, Raut DK. Medical adherence and its predictors in diabetes mellitus patients attending government hospitals in the Indian capital, Delhi, 2013: a cross sectional study. Int J Diabetes Dev Ctries. 2015;35(Suppl 2):95-101.

5. Basu S, Garg S, Sharma N, Singh MM, Garg S. Adherence to self-care practices, glycemic status and influencing factors in diabetes patients in a tertiary care hospital in Delhi. World J Diabetes. 2018;9(5):72-9.

6. Mohan V, Shah S, Saboo B. Current glycemic status and diabetes related complications among type 2 diabetes patients in India: data from the A1chieve study. J Assoc Physicians India. 2013;61 (Suppl. 1):12-5.

7. Basu S, Sharma N. Under-recognised ethical dilemmas of diabetes care in resource-poor settings. Indian J Med Ethics. 2018;3(4):324-6.

8. Alvarenga MA, Komatsu WR, de Sa JR, Chacra AR, Dib SA. Clinical inertia on insulin treatment intensification in type 2 diabetes mellitus patients of a tertiary public diabetes center with limited pharmacologic armamentarium from an upper-middle income country. Diabetol Metab Syndr. 2018;10:77.

\section{Publisher's Note}

Springer Nature remains neutral with regard to jurisdictional claims in published maps and institutional affiliations.

Ready to submit your research? Choose BMC and benefit from:
- fast, convenient online submission
- thorough peer review by experienced researchers in your field
- rapid publication on acceptance
- support for research data, including large and complex data types
- gold Open Access which fosters wider collaboration and increased citations
- maximum visibility for your research: over 100M website views per year
At BMC, research is always in progress.
Learn more biomedcentral.com/submissions

